\title{
The Production and Characterization of Lipases from a Micrococcus and a Pseudomonad
}

\author{
By R. C. LAWRENCE, * T. F. FRYER AND B. REITER \\ University of Reading; The National Institute for Research in Dairying, \\ Shinfield, Reading, Berkshire
}

(Accepted for publication 2I March 1967)

\begin{abstract}
SUMMARY
Extracellular lipase production was a constitutive property of the micrococcus and pseudomonad studied but was considerably influenced by nutritional and physical conditions. The lipase in culture supernatant fluids of the micrococcus was markedly heat resistant but became increasingly more thermolabile with the degree of purification obtained. The hydrolytic activity of partially purified extracellular lipase preparations from each organism was due to a single protein which was identical with a hydrolytic enzyme also found in cell-free extracts of each organism. The lipases from both organisms had general specificity towards ester linkages although the lipase from the micrococcus was markedly more active towards esters containing short chain fatty acids and comparatively less active towards trigylcerides containing long chain acids than was the pseudomonal lipase. The activity of both lipases showed an optimum for all substrates at $\mathrm{pH} 8 \cdot 0-8 \cdot 5$ and did not decrease at higher $\mathrm{pH}$ values, indicating the involvement of an acidic group in the enzyme/ substrate binding. The results of inhibition studies were consistent with the view that both lipases possess a serine-imidazole active centre and are therefore similar to esterolytic enzymes in mammalian systems.
\end{abstract}

\section{INTRODUCTION}

The properties of bacterial lipases have not yet been fully elucidated despite the vast literature that has accumulated. The diversity of the data seems to be partly due to the use of unpurified enzyme preparations and partly to the wide choice of substrates, assay conditions and methods used to determine lipase activity. Lipases form a rather indefinite section of the esterase group of enzymes, but it is useful to distinguish lipases from other esterases by the definition recommended by the International Union of Biochemistry (I961), namely that lipases hydrolyse emulsified esters of glycerol, whereas other esterases hydrolyse dissolved substrates. The choice of any substrate to detect bacterial lipases must be arbitrary, since nothing is known of their natural substrates or their physiological role in the metabolism of the bacteria. The technical difficulties involved in the quantitative estimation of lipase activity (Lawrence, 1967) and the absence of a method readily applicable to routine use have also contributed to the inconsistent results of different workers.

Of almost roo bacteria, Gram-positive and Gram-negative, tested in two recent surveys (Fryer, Reiter \& Lawrence, 1967; Fryer, Lawrence \& Reiter, I967) all produced diffusible lipases, although there was considerable variation in lipolytic activity

* Permanent address: New Zealand Dairy Research Institute, Palmerston North, New Zealand. 
between genera and even between strains of species in the same genus. A Grampositive organism, Micrococcus freudenreichii, NCDO I223, and a Gram-negative organism, Pseudomonas fragi, NCDO 752, which showed the highest lipase activity under the particular conditions of that survey were selected for more detailed study to determine whether gross differences existed between lipase production or the characteristics of the lipase formed by each organism. As it was found to be more difficult to detect lipase activity in liquid cultures than on solid media, a method of estimation was required which was more sensitive than those already in existence. A preliminary account of the use of the agar diffusion assay developed for this purpose has been reported (Lawrence, Fryer \& Reiter, 1967).

\section{METHODS}

Media. The media listed in Table I were used, usually as I $\%(w / v)$ solutions. The organisms were subcultured twice in each of the media before the lipolytic activity was determined.

Chemicals. Trioctanoin, tridecanoin and trilaurin were obtained from Sigma Chemical Co., St Louis, Mo., U.S.A.; tributyrin, triolein and other chemicals from British Drug Houses Limited (BDH). Fresh butter was melted and filtered at $30^{\circ}$ for use as an enzyme substrate. Chloramphenicol was obtained from Parke, Davis and Co., Detroit, Mich. Di-isopropylfluorophosphate (DFP) and diethyl p-nitrophenylphosphate (E600) were gifts from Dr G. C. Cheeseman and Dr P. Andrews, respectively.

Counts of organisms. Colony counts were made for both organisms on nutrient agar by the method of Miles \& Misra (1938). In some experiments extinction measurements of suspensions were done at $610 \mathrm{~m} \mu$ and those were converted into cell counts using predetermined graphs relating extinction to cell counts.

Cell-free extracts. The organisms were grown in Bactopeptone for $\mathrm{I}-2$ days, centrifuged down, washed in saline, re-centrifuged and re-suspended in $0.9 \% \mathrm{NaCl}$ solution. The majority of the pseudomonads were broken as shown by microscopic examination, after $3 \mathrm{~min}$. ultrasonic treatment in a Branson Soniprobe Type I I30A (Dawe Instruments Ltd., London) used at maximum energy and the system kept cold with solid $\mathrm{CO}_{2}+$ ethanol. Ultrasonic treatment for $40 \mathrm{~min}$. was necessary for comparable breakage of the micrococci.

Gel filtration. Sephadex G-I00 gel filtration medium (I40-400 mesh; Pharmacia, Uppsala, Sweden) was allowed to swell for 3 days, and G-200 (140-200 mesh) for at least $\mathrm{I} 4$ days, in $0.2 \mathrm{M}-\mathrm{NaCl}$ containing $0.025 \mathrm{M}-\mathrm{MgCl}_{2}$ before use. Columns $(55 \mathrm{~cm} . \times$ $3 \mathrm{~cm}$. diameter) were packed in the cold with the swollen gels and run at $0-5^{\circ}$.

Partial purification of lipases. The supernatant fluid of the bacterial cultures was two-thirds saturated with ammonium sulphate and the mixture left standing overnight at $4^{\circ}$. The precipitate was deposited by centrifugation, dissolved in a small volume of $0.2 \mathrm{M}-\mathrm{NaCl}$ containing $0.025 \mathrm{M}-\mathrm{MgCl}_{2}$ and passed down a Sephadex $\mathrm{G}$ Ioo column to remove low molecular weight material. The active fractions were pooled, the lipase again precipitated by saturation with ammonium sulphate, re-dissolved in a small volume of the above $\mathrm{NaCl}+\mathrm{MgCl}_{2}$ solution, added to a $\mathrm{G} 200$ Sephadex column and eluted with the same salt solution. Five-ml. fractions were collected and monitored by determining absorption at $280 \mathrm{~m} \mu$ or $230 \mathrm{~m} \mu$ and also by testing for lipolytic activity either by the agar diffusion method or by potentiometric titration. 
Gel electrophoresis. Esterases in the culture supernatant fluids and in freshly harvested bacteria which had been disintegrated by ultrasonic treatment were studied by electrophoresis in polyacrylamide gels at $\mathrm{pH} 7 \cdot 3$ and $8 \cdot 7$, essentially by the method described by Lund (1965). After separation of the proteins by electrophoresis, the gel slides were flooded with freshly prepared buffered solutions containing $0.04 \%$ of either $\alpha$-naphthyl acetate, butyrate or caprylate and $0.0 \mathrm{I} \%(\mathrm{w} / \mathrm{v})$ Fast blue B salt. Esterase activity was shown by the appearance of dark red bands which developed in $2 \mathrm{hr}$ at room temperature.

Estimation of esterase activity. Hydrolysis of o-nitrophenylbutyrate (BDH) was measured by the spectrophotometric estimation of the liberated $o$-nitrophenol at $4 \mathrm{IO} \mathrm{m} \mu$ in $\mathrm{I} \mathrm{cm}$. cuvettes and total volume of $3.2 \mathrm{ml}$. Assay mixtures contained I00 $\mu$ moles tris $+\mathrm{HCl}$ buffers $(\mathrm{pH} 8 \cdot 0$ ) and $7.5 \mu$ moles of $o$-nitrophenylbutyrate (added as a solution in $0.2 \mathrm{ml}$. methanol). In preliminary experiments $p$-nitrophenylacetate was also used (Downey $\&$ Andrews, I965 $b$ ) but the low esterase activities of some cultures were of the same order as the rate of spontaneous hydrolysis of the acetate at $\mathrm{pH} 8$, which made measurements less reliable than those with the more stable $o$-nitrophenylbutyrate.

\section{Estimation of lipase activity}

Potentiometric assay. The initial velocity of lipolysis was followed by continuous titration with $\mathrm{IO}^{-3} \mathrm{M}-\mathrm{NaOH}$ at a constant $\mathrm{pH}$ value at $25^{\circ}$ by using a Radiometer titrator, type TTT Ic, coupled to a Radiometer titrigraph, type SBR 2 C (Radiometer, Copenhagen, Denmark), as described by Downey \& Andrews (I965a). The lipase solution, usually $2-3 \mathrm{ml}$., was brought to $\mathrm{pH} 8 \cdot 0$, at least $7 \mathrm{~min}$. being required before steady conditions were attained (Fig. I). This was noted both in the sample and in its control (boiled enzyme preparation); the reason why this occurred is not understood. The emulsified substrate (either I \% triolein or $5 \%$ tributyrin, stabilized with gum acacia as described by Downey \& Andrews, I $965 a$ ) was then added, the titration being continued for a further $5 \mathrm{~min}$. Controls were also done to check non-enzymic hydrolysis of each substrate. The relationship between an increase in enzyme concentration and lipase activity was slightly non-linear (Fig. I), possibly because of adsorption of some lipase to the glass of the reaction vessel. The assay was found to be unsuitable for the estimation of very small amounts of acid below $\mathrm{pH} 7 \cdot 0$.

Agar diffusion assay. The thin layer agar diffusion method described earlier (Lawrence et al. 1967) was found to be most suitable for the routine estimation of lipase activity and was used for all determinations of lipase activity reported in this paper unless otherwise stated. The diameters of the zones of clearing (in $\mathrm{mm}$.) of emulsions of various trigylcerides in agar, buffered with $0.05 \mathrm{M}$-phosphate, were measured after incubation at the pre-determined optimal temperature of $30^{\circ}$. The assay depends not only upon the solubility of di- and mono-glycerides but also upon the solubility of the calcium salts of the fatty acids produced by hydrolysis. For triglycerides containing fatty acids of twelve or fewer carbon atoms the hydrolysis is indicated by the clearing of the trigylyceride emulsion.

For triglycerides containing high molecular weight fatty acids the zones of hydrolysis show up as increased opaque zones against the emulsion background, presumably as a result of the precipitation of the calcium salts of the liberated fatty acids, since agar is known to contain exchangeable calcium (Cooper, I963). The incorporation of 
a fat-soluble dye into the medium, however, facilitated the detection of lipolytic activity against butterfat. The lipase was added to a phosphate buffered agar gel on which was then placed a lens tissue (Green's, 105), which had been painted with melted butterfat saturated with Victoria blue base. The hydrolysis of the thin uniform layer of butterfat was shown as a blue zone against the red background of unchanged dye.

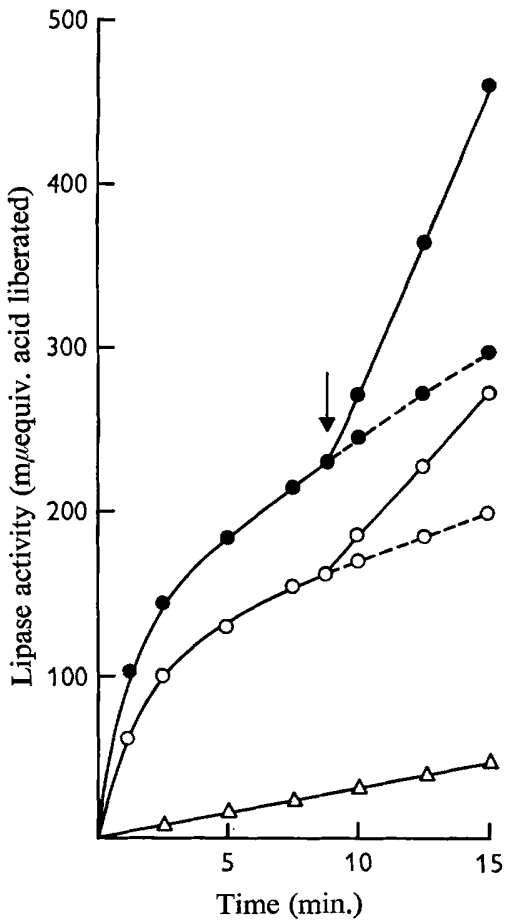

Fig. I

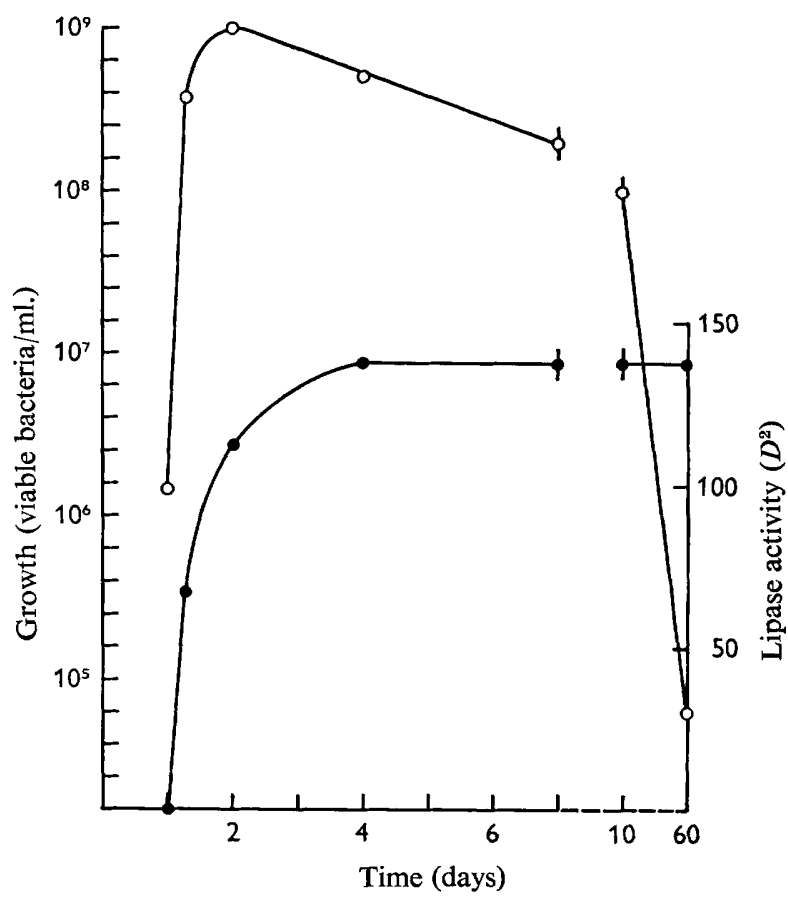

Fig. 2

Fig. I. Effect of concentration of a partially purified lipase preparation from Micrococcus freudenreichii on the rate of hydrolysis of $5 \%$ tributyrin (v/v), emulsified with $10 \%(\mathrm{w} / \mathrm{v})$ gum acacia in a $\mathrm{pH}$ stat. The substrate was added at $\downarrow$ to $0.05 \mathrm{ml}$. enzyme $(\mathrm{O}-\mathrm{O})$ and $0.1 \mathrm{ml}$. enzyme (-). Boiled enzyme controls are shown thus $\left(\mathrm{O}_{-\ldots}\right)$ and $(\bullet--\bullet)$. Substrate control $(\triangle-\triangle)$.

Fig. 2. Effect of extended incubation upon the growth $(\mathrm{O}-\mathrm{O})$ and production of lipase (-) of static cultures of Micrococcus freudenreichii in I \% (w/v) bactopeptone and $0.04 \mathrm{M}$-phosphate $(\mathrm{pH} 7.0)$ at $30^{\circ}$. Lipase activity was measured against emulsified tributyrin $(0 \cdot I \%, \mathrm{v} / \mathrm{v}) . D=$ diameter of zone of hydrolysis.

The correlation between the potentiometric assay and the tributyrin emulsion agar method was good (Fig. 5). The latter method, however, was able to detect lower levels of lipase activity, needed much smaller samples (0.004 ml.) and was considerably more simple to carry out than the potentiometric assay. 


\section{RESULTS}

\section{Factors affecting lipase production}

Many of the conclusions drawn from previous studies on the effect of the growth medium and the conditions of growth on lipase production appeared to be contradictory (see review by Lawrence, 1967). The effect of such factors upon the two organisms used in this investigation was therefore determined in order to obtain optimal conditions for lipase formation.

Effect of the medium. The micrococcus and the pseudomonad were grown in different media containing peptones, Casamino acids and, in some cases, yeast extract. Most media supported good growth which, however, particularly in the case of the pseudomonad, resulted in no measurable lipase activity (Table I). This confirmed a previous report (Nashif \& Nelson, I953) that some samples of peptone were less satisfactory than others as constituents of media for lipase production by bacteria. Lipase activity in the culture supernatant fluids was optimal for both organisms when

\section{Table I. The effect of different media upon the growth and production of lipase by Pseudomonas fragi}

The organism was grown at $25^{\circ}$ in $20 \mathrm{ml}$. lots of medium containing different peptones $(\mathrm{I} \%, \mathrm{w} / \mathrm{v})$ adjusted to $\mathrm{pH} 7.0$ with $\mathrm{NaOH}$. The lipase activity in the culture supernatant fluids was tested after $\mathrm{I} 6 \mathrm{hr}$ and $40 \mathrm{hr}$ incubation, against $0 . \mathrm{I} \%(\mathrm{v} / \mathrm{v})$ tributyrin emulsion. $D=$ diameter of zone of hydrolysis. $+=$ zone of hydrolysis too small to measure.

\begin{tabular}{|c|c|c|c|c|}
\hline \multirow[b]{2}{*}{$\begin{array}{l}\text { Peptone component } \\
\text { in Medium }\end{array}$} & \multicolumn{2}{|c|}{$16 \mathrm{hr}$} & \multicolumn{2}{|c|}{$40 \mathrm{hr}$} \\
\hline & $\begin{array}{l}\text { Growth } \\
\text { (E610) }\end{array}$ & $\begin{array}{c}\text { Lipase } \\
\text { activity } \\
\left(D^{2}\right)\end{array}$ & $\begin{array}{l}\text { Growth } \\
\text { (E6Io) }\end{array}$ & $\begin{array}{c}\text { Lipase } \\
\text { activity } \\
\left(D^{2}\right)\end{array}$ \\
\hline Bacto peptone & 0.74 & $16 \cdot 0$ & 0.95 & $4 \cdot 0$ \\
\hline Bacto proteose peptone & $I \cdot 60$ & + & I.90 & $2 \cdot 3$ \\
\hline Bacto neopeptone & 0.60 & Nil & $I \cdot 10$ & $6 \cdot 8$ \\
\hline Bacto casitone & $1 \cdot 00$ & + & $1 \cdot 90$ & $6 \cdot 8$ \\
\hline Bacto tryptone & $1 \cdot 30$ & + & $2 \cdot 00$ & $3 \cdot 6$ \\
\hline Bacto tryptose & $1 \cdot 05$ & + & $I \cdot 50$ & Nil \\
\hline Bacto Casamino acids & $0 \cdot 29$ & Nil & $1 \cdot 00$ & Nil \\
\hline Oxoid peptone & $I \cdot 20$ & Nil & $1 \cdot 50$ & $6 \cdot 8$ \\
\hline Oxoid tryptone & 1.00 & Nil & $\mathrm{I} \cdot 75$ & Nil \\
\hline Oxoid tryptose & $\mathbf{I} \cdot 75$ & Nil & $I \cdot 90$ & Nil \\
\hline Evans peptone & 1.60 & + & $2 \cdot 00$ & + \\
\hline $\begin{array}{l}\text { Bacto peptone + I \% } \\
\text { Oxoid Lab Lemco }\end{array}$ & $2 \cdot 00$ & + & $2 \cdot 00$ & + \\
\hline $\begin{array}{r}\text { Bacto peptone }+0.2 \% \\
\text { Bacto yeast extract }\end{array}$ & $\mathbf{I} \cdot 75$ & + & $I \cdot 50$ & Nil \\
\hline
\end{tabular}

grown in the Bacto peptone medium, which was therefore used throughout this investigation. Growth and lipase production by the micrococcus was unaffected by the concentration of peptone between 0.5 and $2 \%$ but growth and initial lipase production by the pseudomonad were considerably stimulated by an increase of peptone (Table 2 ). However this lipase initially formed was destroyed after 5-7 days at the higher peptone concentrations. It may be significant that the pseudomonad was strongly proteolytic for casein and gelatine, whereas proteolytic activity by the micrococcus was. not detected. 
While the two organisms produced lipase in media devoid of triglyceride substrates, it was possible that the addition of triglyceride might induce greater lipase production. However, low concentrations of tributyrin and trioctanoin (less than $\mathrm{IO}^{-3} \mathrm{M}$ ) had no significant effect on growth or lipase production although higher concentrations were inhibitory.

Table 2. The effect of concentration of Bacto-peptone on the rate of destruction of the lipase formed by Pseudomonas fragi

The organism was grown at $25^{\circ}$ in Bacto peptone medium containing $0.04 \mathrm{M}$-phosphate buffer ( $\mathrm{pH} \mathrm{7}$.0). Lipase activity in the culture supernatant fluids after $1,3,7$ and $\mathrm{I} 4$ days was tested against $0.1 \%(\mathrm{v} / \mathrm{v})$ tributyrin emulsion. $D=$ diameter of zone of clearing of tributyrin emulsion. $t=$ zone of hydrolysis too small to measure.

\begin{tabular}{|c|c|c|c|c|c|c|c|c|}
\hline \multirow{3}{*}{$\begin{array}{c}\% \\
\text { Bacto } \\
\text { peptone }\end{array}$} & \multicolumn{8}{|c|}{ Period of incubation } \\
\hline & \multicolumn{2}{|c|}{ I day } & \multicolumn{2}{|c|}{3 days } & \multicolumn{2}{|c|}{7 days } & \multicolumn{2}{|c|}{ I4 days } \\
\hline & $\begin{array}{c}\text { Growth } \\
\text { (E6ro) }\end{array}$ & $\begin{array}{c}\text { Lipase } \\
\left(D^{2}\right)\end{array}$ & $\begin{array}{l}\text { Growth } \\
\text { (E6Io) }\end{array}$ & $\begin{array}{c}\text { Lipase } \\
\left(D^{2}\right)\end{array}$ & $\begin{array}{r}\text { Growth } \\
\text { (E6I0) }\end{array}$ & $\begin{array}{c}\text { Lipase } \\
\left(D^{2}\right)\end{array}$ & $\begin{array}{c}\text { Growth } \\
\text { (E6ro) }\end{array}$ & $\begin{array}{c}\text { Lipase } \\
\left(D^{2}\right)\end{array}$ \\
\hline 0.25 & 0.45 & Nil & 0.39 & Nil & 0.35 & Nil & 0.40 & + \\
\hline 0.5 & 0.60 & $12 \cdot 5$ & 0.66 & $16 \cdot 0$ & 0.68 & $24 \cdot 0$ & 0.60 & $9 \cdot 5$ \\
\hline 0.75 & 0.72 & 20.5 & 0.85 & $21 \cdot 0$ & 0.86 & $27 \cdot 0$ & 0.90 & 5.0 \\
\hline $\mathrm{I} \cdot \mathrm{O}$ & 0.80 & 24.0 & $I \cdot I O$ & $25 \cdot 0$ & $x \cdot 00$ & $29 \cdot 0$ & $I \cdot I O$ & + \\
\hline $2 \cdot 0$ & $\mathrm{I} \cdot 20$ & $36 \cdot 0$ & $I \cdot 60$ & $35 \cdot 0$ & $I \cdot 75$ & Nil & 1.80 & Nil \\
\hline
\end{tabular}

Table 3. The effect of temperature upon the lipase activity in supernatant fluids of Pseudomonas fragi cultures

The organism was grown at $25^{\circ}$ in $40 \mathrm{ml}$. Bacto peptone (I \%, w/v) +0.04 M-phosphate buffer $(\mathrm{pH} 7 \cdot 0)$. Lipase activity in the supernatant fluids was tested after $\mathrm{I}, 3$ and $\mathrm{I} 4$ days against $0.1 \%(\mathrm{v} / \mathrm{v})$ tributyrin emulsion. $D=$ diameter of zone of hydrolysis. $+=$ zone of hydrolysis too small to measure.

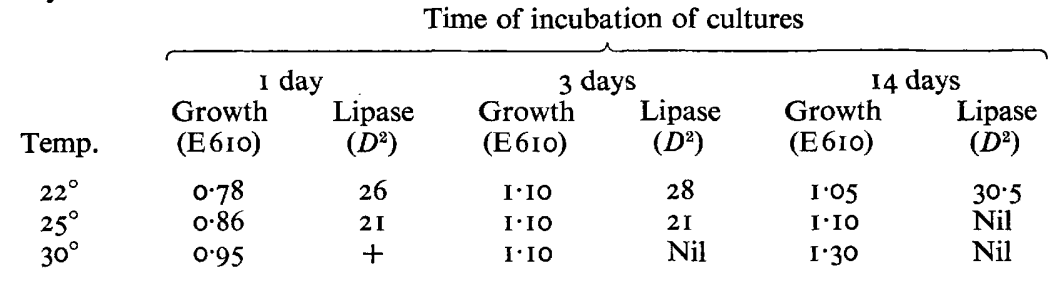

Effect of incubation temperature. The optimum temperature for lipase production by the pseudomonad was $22^{\circ}$ and the lipase initially formed was unaffected by extended incubation at the temperature. The lipase present after I day at $25^{\circ}$ was, however, completely destroyed after 14 days at that temperature and no lipase at all was detected at $30^{\circ}$ (Table 3). Growth of the pseudomonad was not significantly affected by temperatures between $22^{\circ}$ and $30^{\circ}$ but was completely inhibited at $37^{\circ}$.

Incubation temperatures between $22^{\circ}$ and $30^{\circ}$ did not affect lipase production by the micrococcus, and the lipase initially formed was not destroyed by extended incubation between $22^{\circ}$ and $37^{\circ}$. Both growth and lipase production, however, were lower when the micrococcus was grown at $37^{\circ}$.

Effect of aeration of growth medium. When the surface area/volume ratio of static cultures of the organisms was decreased there was a significant decrease in the lipase production per organism by the micrococcus but not by the pseudomonad (Table 4). 


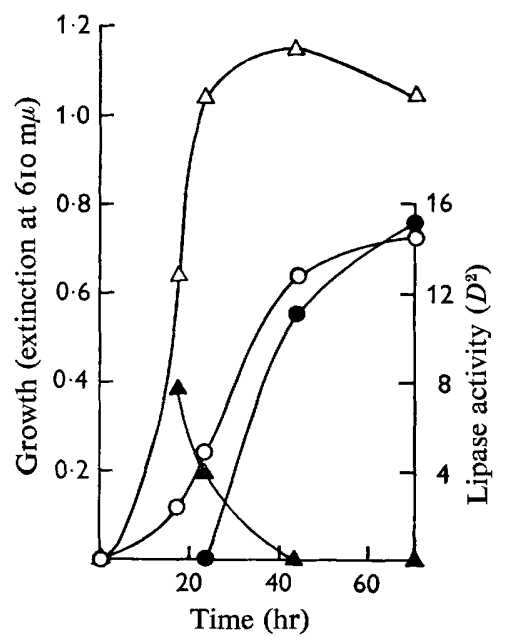

Fig. 3

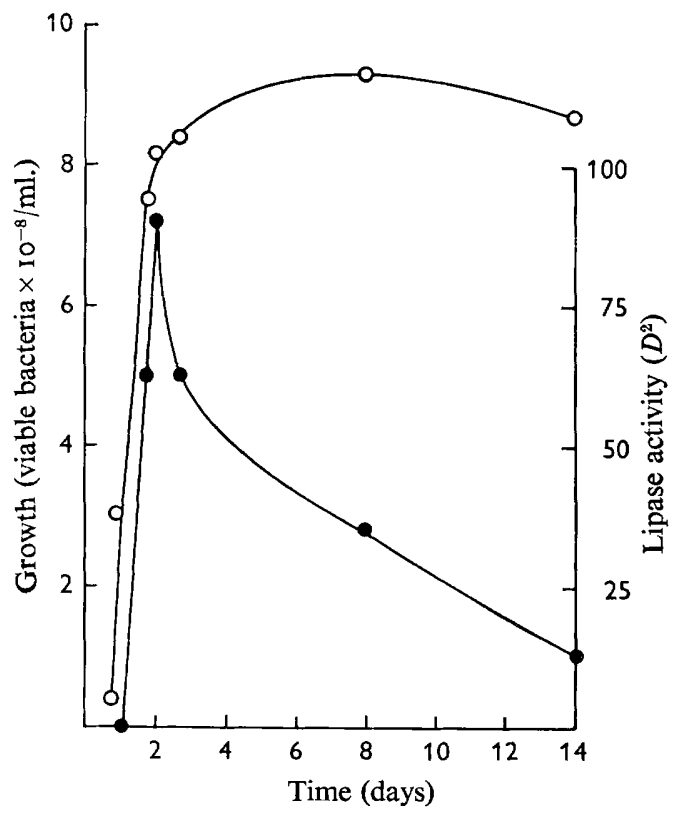

Fig. 4

Fig. 3. Effect of shaking upon the growth $(\Delta-\Delta)$ and lipase production $(\mathbf{\Delta}-\mathbf{\Delta})$ of Pseudomonas fragi at $22^{\circ}$ in bactopeptone $(0.75 \%$, w/v). The growth $(\mathrm{O}-\mathrm{O})$ and lipase production (-) of static cultures were also recorded after the same time intervals. Lipase activity was measured against emulsified tributyrin $(0.1 \%, \mathrm{v} / \mathrm{v}) . D=$ diameter of zone of hydrolysis.

Fig. 4. Effect of extended incubation upon the growth $(\mathrm{O}-\mathrm{O})$ and lipase production (-) of static cultures of Pseudomonas fragi in I \% (w/v) bactopeptone and $0.04 \mathrm{M}-$ phosphate, $\mathrm{pH} 7 \cdot 0$, at $22^{\circ}$. Lipase activity was measured against emulsified tributyrin $(0.1 \%, v / v) . D=$ diameter of zone of hydrolysis.

Table 4. The effect of degree of aeration upon the lipase production per organism of Micrococcus freudenreichii and Pseudomonas fragi

The micrococcus was grown at $30^{\circ}$ for 2 days in the specified volumes of Bacto peptone $(\mathrm{I} \%, \mathrm{w} / \mathrm{v})$ medium in $250 \mathrm{ml}$. centrifuge bottles and the pseudomonad at $22^{\circ}$ in Bacto peptone $(\mathrm{I} \%, \mathrm{w} / \mathrm{v})+0.05 \mathrm{M}$-phosphate buffer $(\mathrm{pH} 7.0) . D$ is the diameter of zone of clearing of $0.1 \%(\mathrm{v} / \mathrm{v})$ tributyrin emulsion.

M. freudenreichii

Lipase activity $\left(D^{2}\right)$

Count $/ \mathrm{ml} . \times 10^{-8}$

Lipase/organism

Pseudomonas fragi

Lipase activity $\left(D^{2}\right)$

Count $/ \mathrm{ml} \times 1 \mathrm{IO}^{-8}$

Lipase/organism
Volume of medium

$\begin{array}{rrr} & & \\ 10 \mathrm{ml} . & 25 \mathrm{ml} . & 100 \mathrm{ml} . \\ 32.5 & 28.0 & 4.5 \\ \mathrm{I} \cdot 2 & 0.8 & 0.8 \\ 4.9 & 6.0 & 1.0 \\ & & \\ 30.5 & 1 \mathrm{I} \cdot 0 & 5.0 \\ 7.4 & 4.2 & 1.9 \\ 1.2 & 0.8 & 1.0\end{array}$


Lipase production by static cultures of the micrococcus increased to a maximum after incubation for 48-72 hr and did not decrease with further incubation (Fig. 2). Lipase production by static cultures of the pseudomonad increased gradually to a maximum after about $72 \mathrm{hr}$ but decreased markedly on prolonged incubation (Figs. 3, 4).

Shaking the cultures to increase aeration resulted in increased growth and lipase activity in the first $24 \mathrm{hr}$ with both organisms, but the lipase activity produced by the pseudomonad decreased rapidly on continued shaking. In a typical experiment, no activity was detected after shaking for $42 \mathrm{hr}$ at $22^{\circ}$ (Fig. 3).

Effect of initial $p H$ value of growth medium. The lipase activity obtained from the pseudomonad grown in a medium initially at $\mathrm{pH} 6$ was three to four times that at $\mathrm{pH}$ 8. The initial $\mathrm{pH}$ value of the medium was of little significance for lipase production from the micrococcus, although over extended periods an initial value between $\mathrm{pH} 7$ and 8 gave slightly greater yields of lipase.

\section{Extracellular nature of the lipases}

Lipase activity was found in the supernatant fluids of young cultures during the logarithmic phase of growth of both organisms. Lipase production and numbers of organisms reached a maximum at almost the same time (Figs. 2-4). The finding of enzyme in the culture fluid may possibly result from the death or lysis of a small fraction of the organisms in a culture, but lipase activity did not increase on prolonged incubation of cultures of the micrococcus (Fig. 2) despite a great decrease in the number of viable organisms, and the activity actually decreased in cultures of the pseudomonad (Fig. 4). Similarly, the death of the micrococci occurred more rapidly when the $\mathrm{pH}$ value decreased below $7 \cdot 0$ but the lipase activity did not increase. The activity of a suspension of washed pseudomonads disrupted by ultrasonic treatment for $3 \mathrm{~min}$. was at least sixty times less than that found in the supernatant fluid. The activity of lipase preparations from culture supernatant fluids of the pseudomonad was not affected by the same period of ultrasonic treatment.

Thick suspensions of whole organisms, the culture supernatant fluids and the cellfree extracts of organisms showed the same relative lipolytic activity towards the various substrates, indicating that the extracellular and intracellular enzymes were identical. Whole organisms which had been heated at $100^{\circ}$ for $2 \mathrm{~min}$. showed no activity.

\section{Examination of partially purified lipase preparations}

Behaviour on Sephadex columns. The elution of concentrated lipase preparations of both organisms on Sephadex G Ioo with salt solutions (0.02 $\mathrm{M}-\mathrm{NaCl}+0.025 \mathrm{M}-\mathrm{MgCl}_{2}$ ) resulted in a single peak of lipase activity, the yield by this purification procedure being about $40 \%$ of the original activity of the supernatant fluid. Two peaks were obtained, however, when the lipase preparations of both organisms were eluted on Sephadex G 200 (Fig. 5). The fractions containing each peak showed the same relative activity towards different soluble and emulsified substrates, and the addition of inhibitors decreased the activity towards these substrates by the same proportion. It seems likely therefore that the activity obtained on Sephadex G 200 was due to a single enzyme in each lipase preparation.

The rate of elution of the lipase activity from the Sephadex G 200 columns also allowed an approximate molecular weight to be assigned to the lipases. The columns were calibrated with proteins of known molecular weight, according to the method 
described by Andrews (I965). Thyroglobulin (mol. wt. 670,000), $\gamma$-globulin (mol. wt. I60,000), serum albumin (mol. wt. 67,000) and cytochrome $c$ (mol. wt. I2,000) were used. The elution volumes of the peaks of activity off Sephadex G 200 columns (Fig. 5) would indicate that the lipase activity was associated with proteins of molecular weights of about 25,000 and 250,000 .

Thermostability of the lipases. The lipase in cultures of the micrococcus was extremely heat resistant, as were also the unpurified ammonium sulphate precipitates, which lost only $20 \%$ of their lipase activity on boiling for $5 \mathrm{~min}$. and could be stored for at least 6 months at $4^{\circ}$ without loss of activity. The thermostability of the micrococcal lipase was dependent, however, upon its degree of purification. The lipase activity of

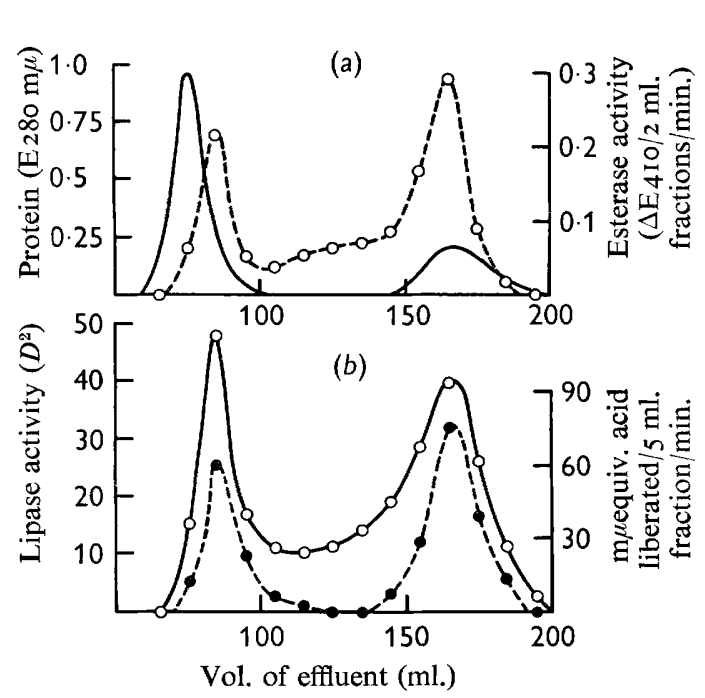

Fig. 5

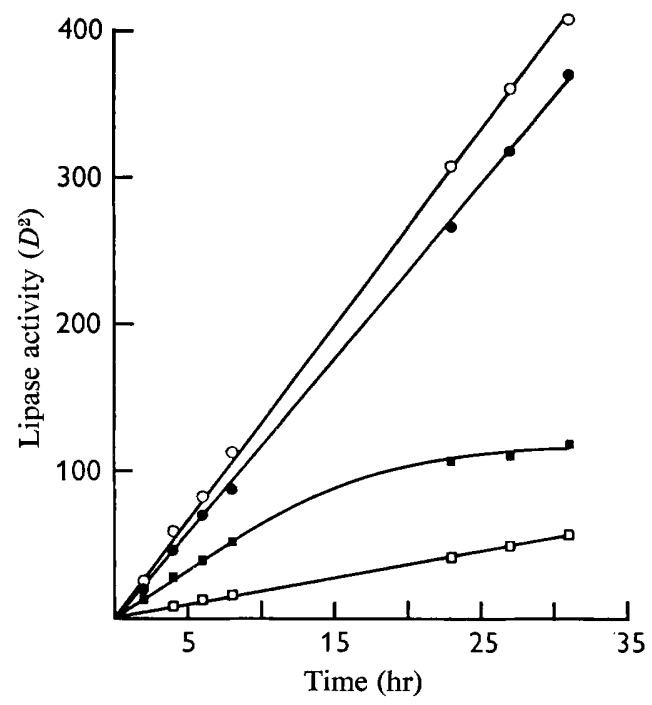

Fig. 6

Fig. 5. Gel filtration of a concentrated lipase preparation from Micrococcus freudenreichii on Sephadex G. 200 columns with $0.2 \mathrm{M}-\mathrm{NaCl}+0.025 \mathrm{M}-\mathrm{MgCl}_{2}$ as eluant; $(a)$ material absorbing at $280 \mathrm{~m} \mu$ (-) and esterase activity against o-nitrophenylbutyrate $\left(\mathrm{O}_{-}-\mathrm{O}^{-}\right)$; $(b)$ lipase activity against emulsified tributyrin $(0.1 \%, v / v)$ by the agar diffusion assay $(\mathrm{O}-\mathrm{O})$ and against emulsified tributyrin $(5 \%, \mathrm{v} / \mathrm{v})$ using a $\mathrm{pH}$ stat $\left(-_{-}-D=\right.$ diameter of zone of hydrolysis.

Fig. 6. The relationship between time of incubation and the zones of hydrolysis obtained on $0 . \mathrm{I} \%(\mathrm{v} / \mathrm{v})$ tributyrin $(\mathrm{O}-\mathrm{O})$, trioctanoin $(-\mathrm{O}-\mathrm{O})$, triolein $(\square-\square)$ and the butterfat + Victoria Blue substrate (_- ) by a partially purified lipase of Micrococcus freudenreichii. $D=$ diameter of zone of hydrolysis.

fractions from Sephadex Groo and G200 columns was completely destroyed by heating at $70^{\circ}$ for $2 \mathrm{~min}$. and lost $50 \%$ of their activity in $48 \mathrm{hr}$ at $4^{\circ}$. The major protective agent in impure preparations appeared to be the peptone of the growth medium, since ethanol precipitates of the enzyme, which were relatively uncontaminated with peptone, were considerably more heat labile than were more impure preparations precipitated by ammonium sulphate.

The lipase from the pseudomonad was relatively more heat sensitive than that from the micrococcus. A preparation of pseudomonal lipase obtained by precipitation with ammonium sulphate lost all activity at $100^{\circ}$ for $3 \mathrm{~min}$. and fractions from Sephadex columns lost $90 \%$ of their activity in $72 \mathrm{hr}$ at $4^{\circ}$. 
Stability of the micrococcal lipase at various $p H$ 's. The partially purified micrococcal lipase was incubated at $30^{\circ}$ for $24 \mathrm{hr}$ with phosphate buffers at values between $\mathrm{pH} 4^{\cdot 8}$ and $8 \cdot 0$. The supernatant fluids from unshaken flasks showed significantly decreased lipase activity below pH 5.5 (Table 5 ) but this decrease did not take place in shaken flasks. Presumably the lipase was precipitated but not inactivated below $\mathrm{pH} 5 \cdot 5$. The loss of activity by precipitation of the lipase with decrease in $\mathrm{pH}$ value may explain the decrease upon prolonged incubation of the initial activity of supernatant fluids of micrococcal cultures grown in media containing glucose.

\section{Table 5. The effect of $\mathrm{pH}$ value upon the activity of partially purified lipase from Micrococcus freudenreichii}

Samples of the lipase solution were incubated at $30^{\circ}$ for 24 hri in phosphate (O.I M) buffers of different $\mathrm{pH}$ values. The lipase activity of the supernatant fluids and the shaken suspensions were tested against $0 . \mathrm{I} \%(\mathrm{v} / \mathrm{v})$ tributyrin. $D=$ the diameter of zone of hydrolysis. $+=$ zone of hydrolysis too small to measure.

$\begin{array}{ccc}\mathrm{pH} & \begin{array}{c}\text { Supernatant } \\ \text { fluid }\end{array} & \text { Suspension } \\ 4 \cdot 8 & + & \text { I I5 } \\ 5 \cdot 3 & 75 & \mathrm{I} 30 \\ 6 \cdot 0 & \mathrm{I} 60 & \mathrm{I} 55 \\ 6 \cdot 8 & 140 & \mathrm{I25} \\ 8 \cdot 0 & 170 & \mathrm{I} 65 \\ \text { Control } & 160 & 155 \\ \text { (water) } & & \end{array}$

Substrate specificity of lipases. Partially purified preparations of the extracellular lipases from the micrococcus and from the pseudomonad hydrolysed triglycerides containing short chain or long chain fatty aids. In the agar diffusion method of lipase assay the extent of hydrolysis was proportional to the area of the zone of activity. The extent of hydrolysis for each synthetic triglyceride was proportional to the period of incubation and remained linear for at least $30 \mathrm{hr}$ (Fig. 6), although the hydrolysis of butterfat, measured by the indirect Victoria blue method, was linear for about $\mathrm{I} 5 \mathrm{hr}$ only.

The two lipases showed considerably less activity, as measured by the agar diffusion method, towards butterfat and triolein than towards synthetic triglycerides containing low molecular weight fatty acids. The inhibitory effect of the liberated oleic acid upon lipase activity (see below, section on inhibitors) over an extended incubation period may be significant, since the liberation of acid from triolein by the micrococcal lipase over an incubation period of $5 \mathrm{~min}$. at controlled $\mathrm{pH}$ value was almost identical to that of tributyrin.

A linear relationship was also obtained when the logarithms of dilutions of the concentrated lipase preparations were plotted against the diameters of the zone of hydrolysis obtained with emulsions of various triglycerides (Fig. 7). The points where these straight lines cut the axis are the minimal lipase concentrations which give discernible zones with a particular substrate. These could be calculated and confirmed by experiment. A dilution of $I / 17,800$ of the partially purified micrococcal lipase was the least concentration that gave a zone with tributyrin emulsion, $1 / 3000$ with tridecanoin emulsion and $\mathrm{I} / 205$ with butterfat + Victoria blue (Fig. 7). The corresponding minimal 
dilutions of the partially purified pseudomonad preparation were I/360, I/I IO and $\mathrm{I} / 35$, respectively (Fig. 8). Heating the partially purified lipase preparations at $80^{\circ}$ for 2 min. completely destroyed their activity against all substrates, showing that nonenzymic hydrolysis was not responsible.

When the concentration of tributyrin was increased the zone of clearing obtained in a given time with a lipase preparation was decreased (Fig. 9). The sensitivity of the tributyrin emulsion assay was thus dependent upon the concentration of tributyrin used. A I \% tributyrin emulsion gave zones that were approximately equivalent to those obtained with the butterfat + Victoria blue substrate under the assay conditions used.

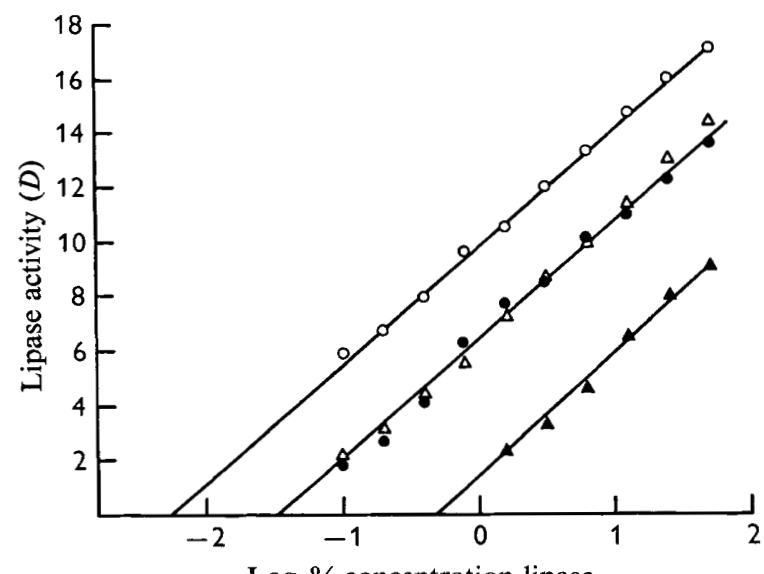

Log $\%$ concentration lipase.

Fig. 7

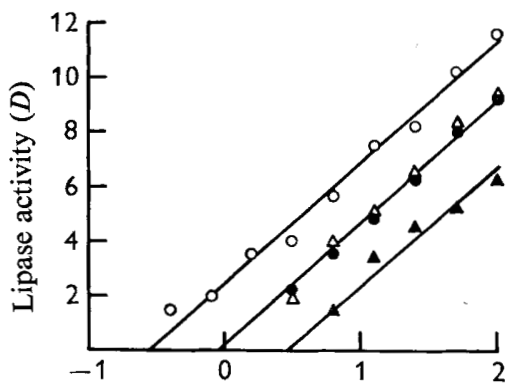

Log. $\%$ concentration lipase

Fig. 8

Fig. 7. The relationship between the diameter of zones of hydrolysis of equimolecular concentrations of various triglycerides and logarithm percentage concentrations of the partially purified lipase of Micrococcus feudenreichii after incubation for $19 \mathrm{hr}$ at $30^{\circ} .0 . \mathrm{I} \%(\mathrm{v} / \mathrm{v})$ tributyrin $(\mathrm{O}-\mathrm{O}), 0.17 \%(\mathrm{v} / \mathrm{v})$ trioctanoin $(--\bullet), 0.2 \%(\mathrm{v} / \mathrm{v})$ tridecanoin $(\triangle-\triangle)$ and butterfat-Victoria Blue $(\mathbf{\Lambda}-\mathbf{\Lambda}) . D=$ diameter of zone of hydrolysis.

Fig. 8. The relationship between the diameter of zones of hydrolysis of equimolecular concentrations of various triglycerides and logarithm percentage concentrations of the partially purified lipase of Pseudomonas fragi after incubation for $\mathrm{Ig} \mathrm{hr}$ at $30^{\circ} .0 . \mathrm{I} \%(\mathrm{v} / \mathrm{v})$ tributyrin $(\mathrm{O}-\mathrm{O}), 0.17 \%(\mathrm{v} / \mathrm{v})$ trioctanoin $(--0), 0.2 \%(\mathrm{v} / \mathrm{v})$ tridecanoin $(\triangle-\triangle)$ and butterfat + Victoria Blue $(\boldsymbol{\Lambda}), D=$ diameter of zone of hydrolysis.

Esterase activity. The micrococcal lipase preparations also showed marked activity towards simple esters such as $p$-nitrophenylacetate and $o$-nitrophenylbutyrate. When the rates of hydrolysis (change in extinction/min.) were appropriately corrected for spontaneous hydrolysis of the acetate, the esterase from the micrococcus appeared to be equally active against both esters. A Lineweaver-Burk plot of $\mathrm{I} / v$ against $\mathrm{I} / \mathrm{s}$ and also a plot of $v$ against $v / s$ (Dowd \& Riggs, 1965) were both linear, giving $K_{m}$ values of $5 \times 10^{-5} \mathrm{M}$ and $2.4 \times 10^{-5} \mathrm{M}$, respectively, for $o$-nitrophenylbutyrate. The linearity of these relationships suggests that a single esterase was attacking the substrate.

The similarity of the $\mathrm{pH} /$ activity plots for hydrolysis of $o$-nitrophenylbutyrate and emulsified tributyrin (Fig. Io) by the micrococcal lipase suggests that only one enzyme was involved in the hydrolysis of both soluble and emulsified substrates. The estimated $\mathrm{pK}$ values for the hydrolysis of $o$-nitrophenylbutyrate by the micrococcal lipase were 
$7 \cdot 3$ in phosphate and $7 \cdot \mathrm{I}$ in tris buffer. Similar $\mathrm{pH} /$ activity plots were obtained with the lipase preparation from the pseudomonad. The latter, however, showed almost no activity towards soluble aromatic esters, which was consistent with its comparatively greater activity towards emulsified triglycerides containing high molecular weight fatty acids than the micrococcal lipase.

Gel electrophoresis. Concentrated lipase preparations from the supernatant fluids of the micrococcal cultures were shown by gel electrophoresis at $\mathrm{pH} 7.3$ and 8.7 to contain a single esterase which hydrolysed esters of $\alpha$-naphthol. The acetate and butyrate were attacked more readily than the octanoate. Gel electrophoresis of cellfree extracts of the organism also showed only one esterase which was apparently identical with the enzyme found in the supernatant fluids.

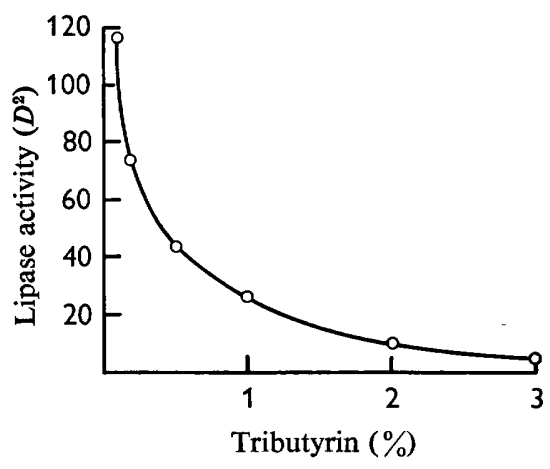

Fig. 9

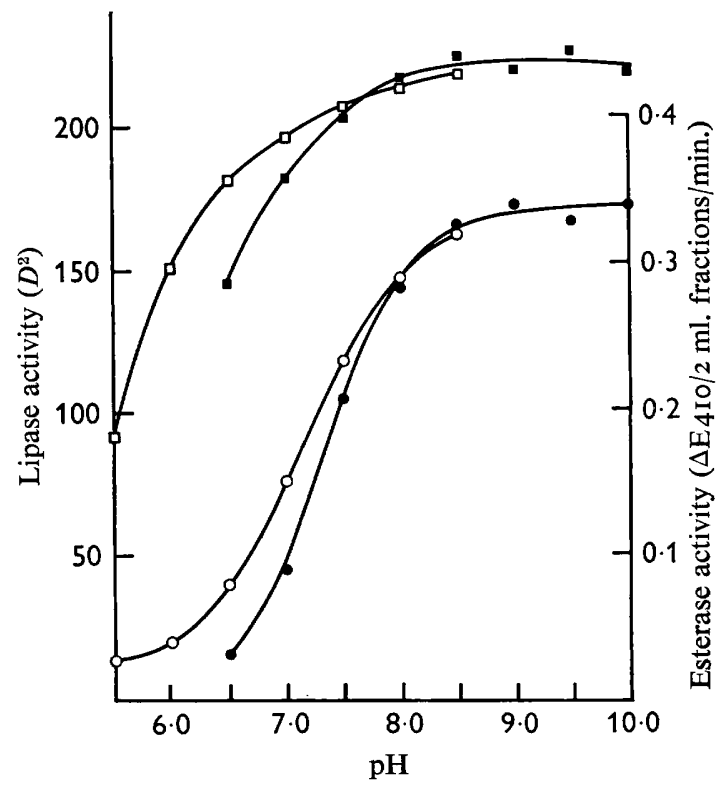

Fig. 10

Fig. 9. The relationship between time of incubation and the zones of hydrolysis obtained on emulsions of different concentrations of tributyrin by a partially purified lipase of Microccocus freudenreichii. $D=$ diameter of zone of hydrolysis.

Fig. Io. Effect of $\mathrm{pH}$ value and buffer system on the rate of hydrolysis of tributyrin $(0.1 \%$, $\mathrm{v} / \mathrm{v}$ ) and $o$-nitrophenylbutyrate by a partially purified lipase from Microccocus freudenreichii; $o$-nitrophenylbutyrate in phosphate $(\mathrm{O}-\mathrm{O})$ and tris $\mathrm{HCl}(-)$ buffers, tributyrin in phosphate $(\square-\square)$ and tris $\mathrm{HCl}(\square-\square)$ buffers. $D=$ diameter of zone of hydrolysis.

Lipase preparations from culture supernatant fluids of the pseudomonad showed only one weak band of hydrolytic activity on gel electrophoresis, whereas a second extremely weak band was also detected in cell-free extracts. These bands ran further than the band of hydrolytic activity associated with the lipase preparation from the micrococcus. The weak bands of activity obtained using esters of $\alpha$-naphthol emphasized the relatively low activity towards soluble esters of the lipase preparation from the pseudomonad as compared to that from the micrococcus. 
Dialysis of partially purified micrococcal lipase. Active fractions from Sephadex columns were pooled and the lipase concentrated by precipitation with ammonium sulphate. The precipitate was dissolved in water and dialysed against de-ionized water for 3 days, but the loss in activity was not greater than for non-dialysed controls, indicating the absence of a dialysable co-factor.

Table 6. The inhibitory effect of metallic ions upon the activity of a partially purified preparation of lipase Micrococcus freudenreichii

Lipase activity was determined at $\mathrm{pH} 8.0$ against $0.1 \%(\mathrm{v} / \mathrm{v})$ tributyrin emulsion in tris and phosphate buffers and against $o$-nitrophenylbutyrate $(o$-NPB) in tris buffer. The metal ions were in contact with the enzyme for $60 \mathrm{~min}$. before the assays were done. *Histidine and EDTA added to annul the inhibition, as described in text.

\begin{tabular}{|c|c|c|c|c|c|}
\hline \multirow[b]{3}{*}{ Metal } & \multirow{3}{*}{$\begin{array}{l}\text { Concentration } \\
\text { (M) }\end{array}$} & \multirow[b]{3}{*}{$\begin{array}{l}\text { Re-activation* } \\
\quad\left(10^{-3} \mathrm{M}\right)\end{array}$} & \multicolumn{3}{|c|}{ Inhibition (\%) } \\
\hline & & & \multirow[b]{2}{*}{$\begin{array}{c}o-\mathrm{NPB} \\
\text { (tris) }\end{array}$} & \multicolumn{2}{|c|}{ Tributyrin } \\
\hline & & & & (tris) & (phosphate) \\
\hline \multirow[t]{5}{*}{$\mathrm{Zn}$} & $1 \times 10^{-3}$ & - & 100 & 93 & 48 \\
\hline & $5 \times 10^{-3}$ & - & 100 & 54 & 44 \\
\hline & $5 \times 10^{-4}$ & - & 90 & 44 & 20 \\
\hline & $5 \times 10^{-4}$ & Histidine & 0 & IO & 37 \\
\hline & - & Histidine & 0 & 0 & 0 \\
\hline $\mathrm{Zn}$ & $5 \times 10^{-4}$ & EDTA & 36 & 30 & 29 \\
\hline- & - & EDTA & 35 & 40 & 0 \\
\hline \multirow[t]{5}{*}{$\mathrm{Hg}$} & $1 \times 10^{-3}$ & - & 100 & 40 & 100 \\
\hline & $5 \times 10^{-8}$ & - & 92 & 21 & 70 \\
\hline & $5 \times 10^{-4}$ & - & 74 & 15 & 47 \\
\hline & $5 \times 10^{-4}$ & Histidine & 14 & 0 & 0 \\
\hline & $5 \times 10^{-4}$ & EDTA & 35 & 0 & 0 \\
\hline
\end{tabular}

Inhibition of the lipases

Effect of metals. Zinc and mercuric ions were the most inhibitory metal ions of the wide range tested against both lipases, the inhibitory effect being annulled by histidine and less completely by EDTA (Table 6). Copper, nickel, cadmium and beryllium also partially inhibited the activity, in that order of decreasing effectiveness.

Effect of non-metallic inhibitors. The most effective inhibitor against the partially purified lipase of the micrococcus, and to a lesser extent of the pseudomonad lipase, was diethyl $p$-nitrophenylphosphate (E6oo). Di-isopropylfluorophosphate (DFP) was considerably less effective (Table 7). The degrees of inhibition of the activity of the lipase preparations against both emulsified tributyrin and soluble $o$-nitrophenylbutyrate were almost identical.

The specific reagent for thiol active centres, $p$-hydroxymercuribenzoate, was without effect and 2,4-dinitrofluorobenzene was inhibitory only in high concentrations (Table 7). Partially purified lipase preparations were inhibited by high concentrations of oleic acid, confirming similar findings for the lipases of Pseudomonas aeruginosa (Sierra, 1957), and P. fragi (Smith \& Alford, 1966), and were partially inhibited (30-40\%) by EDTA in tris buffer (Table 7). The sensitivity of the lipases to both EDTA and oleic acid depended, however, upon their degree of purity, since unpurified preparations of lipase were unaffected.

Sodium fluoride was non-inhibitory for the lipases from both organisms, unlike its reported effect on the esterases of mycobacteria (Cohen, Kurshnick \& Purdy, 1953) 
Table 7. The effect of inhibitors upon the activity of a partially purified lipase preparation from Micrococcus freudenreichii

Activity was determined at $\mathrm{pH} 8.0$ against $0.1 \%(\mathrm{v} / \mathrm{v})$ tributyrin emulsion (in both tris and phosphate buffer) and $o$-nitrophenylbutyrate (o-NPB) in tris buffer. The inhibitors were in contact with the enzyme for $60 \mathrm{~min}$. before the assays were done.

\begin{tabular}{|c|c|c|c|c|}
\hline \multirow[b]{3}{*}{ Inhibitor } & \multirow[b]{3}{*}{$\begin{array}{l}\text { Concentration } \\
\text { (M) }\end{array}$} & \multicolumn{3}{|c|}{ Inhibition $(\%)$} \\
\hline & & \multirow[b]{2}{*}{$\begin{array}{c}o-\mathrm{NPB} \\
\text { (tris) }\end{array}$} & \multicolumn{2}{|c|}{ Tributyrin } \\
\hline & & & (tris) & (phosphate) \\
\hline $\mathrm{E} 600^{*}$ & $2 \times 10^{-4}$ & 100 & 100 & 100 \\
\hline DFP $\dagger$ & $\begin{array}{l}2 \times 10^{-3} \\
2 \times 10^{-4}\end{array}$ & $\begin{array}{l}80 \\
17\end{array}$ & $\begin{array}{l}91 \\
\text { II }\end{array}$ & $\begin{array}{l}90 \\
20\end{array}$ \\
\hline EDTA & $\begin{array}{l}2 \times 10^{-2} \\
2 \times 10^{-3} \\
2 \times 10^{-4}\end{array}$ & $\begin{array}{r}35 \\
40 \\
0\end{array}$ & $\begin{array}{r}37 \\
38 \\
0\end{array}$ & $\begin{array}{l}0 \\
0 \\
0\end{array}$ \\
\hline 2,4-DNFB $\ddagger$ & $\begin{array}{l}2 \times 10^{-2} \\
1 \times 10^{-2}\end{array}$ & $\begin{array}{r}100 \\
48\end{array}$ & $\begin{array}{l}90 \\
60\end{array}$ & $\begin{array}{l}94 \\
57\end{array}$ \\
\hline Sodium oleate & $\begin{array}{l}2 \times 10^{-3} \\
2 \times 10^{-4}\end{array}$ & $\begin{array}{l}72 \\
12\end{array}$ & $\begin{array}{r}70 \\
0\end{array}$ & $\begin{array}{r}81 \\
0\end{array}$ \\
\hline & $\begin{array}{l}\text { o, diethyl } p-n \\
\text { P, di-isopropy } \\
\text {-DNFB, } 2,4-d\end{array}$ & $\begin{array}{l}\text { enylphos } \\
\text { ophospha } \\
\text { luorobenz }\end{array}$ & & \\
\hline
\end{tabular}

Table 8. The effect of organophosphorus compounds on the growth and lipase activity of cultures of Micrococcus freudenreichii and Pseudomonas fragi

The micrococcus and the pseudomonand were grown at $30^{\circ}$ and $\mathbf{2 2}^{\circ}$, respectively, for $20 \mathrm{hr}$ in $10 \mathrm{ml}$. Bacto peptone $(0.75 \%$ w/v) medium containing $0.05 \mathrm{M}$-phosphate buffer $(\mathrm{pH} 7.0)$ and either the specified concentrations of inhibitors in ethanol or similar amounts of ethanol as controls. Lipase activity of the culture supernatant ffuids was determined against $0.1 \%(\mathrm{v} / \mathrm{v})$ tributyrin emulsion. $D=$ the diameter of the zone of hydrolysis. $+=$ zone of hydrolysis too small to measure.

\begin{tabular}{|c|c|c|c|c|c|}
\hline & & & & & \\
\hline & & $\begin{array}{c}\text { Growth } \\
\text { (E6Io) }\end{array}$ & $\begin{array}{c}\text { Lipase } \\
\left(D^{2}\right)\end{array}$ & $\begin{array}{c}\text { Growth } \\
\text { (E6Io) }\end{array}$ & $\begin{array}{c}\text { Lipase } \\
\left(D^{2}\right)\end{array}$ \\
\hline $\mathrm{E} 600^{*}(\mathrm{M})$ & $\begin{array}{l}10^{-4} \\
10^{-5}\end{array}$ & $\begin{array}{l}0.54 \\
0.50\end{array}$ & $\begin{array}{c}\text { Nil } \\
+\end{array}$ & $\begin{array}{l}0.42 \\
0.76\end{array}$ & $\begin{array}{l}26 \cdot 0 \\
26 \cdot 0\end{array}$ \\
\hline $\mathrm{DFP} \dagger(\mathrm{M})$ & $\begin{array}{l}10^{-4} \\
10^{-5}\end{array}$ & $\begin{array}{l}0.58 \\
0.58\end{array}$ & $\begin{array}{l}18 \cdot 5 \\
22 \cdot 0\end{array}$ & $\begin{array}{l}0.47 \\
0.78\end{array}$ & $\begin{array}{l}20 \cdot 5 \\
26 \cdot 0\end{array}$ \\
\hline $\begin{array}{r}\text { Ethanol I } \\
0.1\end{array}$ & & $\begin{array}{l}0.56 \\
0.54\end{array}$ & $\begin{array}{l}18 \cdot 5 \\
20.5\end{array}$ & $\begin{array}{l}0.56 \\
0.74\end{array}$ & $\begin{array}{l}30.5 \\
30.5\end{array}$ \\
\hline
\end{tabular}

and a staphylococcal lipase (Drummond \& Tager, 1959). Smith, Worrell \& Swanson (1949) reported that bacterial esterases were inhibited by chloramphenicol, but even high concentrations were found to be ineffective in the present work. Eserine between $\mathrm{IO}^{-5}$ and $\mathrm{IO}^{-2} \mathrm{M}$ was also without effect upon the lipases from either organism.

Effect of organophosphorus compounds upon growth of the organisms. Growth of the microccoccus was unimpaired by the inclusion of low concentrations of E600 to the 
medium although lipase activity in the culture supernatants was completely inhibited (Table 8). Low concentrations of DFP were without significant effect upon either growth of the micrococcus or its lipase activity. As the inhibitors were made up originally as $\mathrm{IO}^{-2} \mathrm{M}$ solutions in anhydrous ethanol, controls with equivalent concentrations of ethanol+enzyme preparation were made. Neither of the above organophosphorus compounds was effective in inhibiting growth of the pseudomonad or its extracellular lipase activity. This is consistent with the finding (Mounter \& Tuck, I956) that Gram-negative bacteria hydrolyse organosphorous compounds more readily than do Gram-positive bacteria.

\section{DISCUSSION}

The extracellular nature of the lipases found in the supernatant fluids of young cultures of the micrococcus and the pseudomonad is in agreement with similar reports of extracellular lipase production by Pseudomonas fragi (Mencher, Ng \& Alford, 1965) and by lactic acid bacteria (Fryer et al. 1967). The production of diffusible lipases by young cultures of over Ioo strains of Gram-positive catalase-positive cocci, Gramnegative rods and lactic acid bacteria, taken at random (Fryer et al. 1967), is, in addition, tentative evidence that extracellular lipase production may be a general property of most, if not all, bacteria. The amounts of intracellular lipase detected may simply be a measure of the inefficiency of the process for the release of most of the new enzyme into the culture fluid and have no specific intracellular function (Lampen, 1965).

The extent to which extracellular lipase is formed, however, varies considerably, even between strains of the same species of organism and is markedly influenced by different nutritional and physical conditions. The lipase initially produced by the pseudomonad, but not that of the microccocus, was destroyed by prolonged aeration, incubation at a temperature above $22^{\circ}$ or by growing the organism in high concentrations of bactopeptone. It may be significant that the pseudomonad also produced an active extracellular proteinase, whereas the micrococcus did not. Preliminary investigations indicate that the proteinase activity of the pseudomonad is correlated with the destruction of the lipase initially produced.

Lipase formation by the two organisms studied in this paper was not enhanced by the addition of tributyrin or trioctanoin to the growth medium, which suggests that these bacterial lipases are not inducible in the generally accepted sense. The classification of enzymes as inducible or constitutive is, however, somewhat arbitrary, since constitutive enzyme formation is not itself a completely fixed property but varies depending on previous growth conditions (Davies, 1963). It seems unlikely that the formation of extracellular lipases plays an essential role in the metabolism of the micrococcus since its growth was unaffected by concentrations of the organophosphorus compound E600 which completely suppressed lipase activity in the culture supernatant fluids.

Lipase activity in the supernatant fluids of cultures of the micrococcus, and to a lesser extent in those of the pseudomonad, was markedly heat resistant. It is probable that the peptone of the growth medium stabilized the lipase, since the thermostability of the enzyme was dependent upon its degree of purification and other bacterial lipases have been shown to be stabilized by the presence of proteins (Virtanen, 1934).

The elution of concentrated preparations from both organisms on Sephadex G roo resulted in a single peak of lipase activity, but two peaks were obtained by elution on 
Sephadex $G$ 200. The fractions containing each peak showed the same relative activity towards different soluble and emulsified substrates and these rates were decreased to the same extent when each peak was treated with inhibitors, suggesting that the activity was due to a single enzyme in each lipase preparation. It is reasonable to assume that the activity in the first peak was due to lipases either in a polymerized form or associated with inactive high molecular weight material, and that the later fractions which showed lipase activity contained lipase in a monomer form. The lipases from both organisms are therefore estimated to have molecular weights of about 25,000 , which is consistent with the view that bacterial exo-enzymes are usually relatively small proteins (Pollock, 1962). Similar behaviour by pancreatic lipase when eluted from Sephadex gel columns has been reported (Gelotte, 1964).

It is generally accepted that although bacterial esterases show a very low degree of specificity towards ester linkages in general, there is a certain degree of specificity in regard to the chain length of the acid (Alford \& Pierce, I963). The results with the micrococcal lipase emphasize, however, the inadequate basis for a general distinction between esterases and lipases in micro-organisms, since both soluble esters and emulsified triglycerides containing short and long chain fatty acids were readily attacked. The optimal $\mathrm{pH}$ values for the hydrolysis of soluble $o$-nitrophenylbutyrate and emulsified triglycerides were identical, which indicates that the same enzyme was exerting a corresponding effect on each of the substrates. The relative rates of hydrolysis of both soluble and insoluble substrates by many different batches of the lipase preparations were very similar, even after considerable purification had been achieved, and were decreased to the same extent by inhibitors. The detection of a single hydrolytic enzyme only by gel electrophoresis of partially purified lipase preparations from culture supernatant fluids and cell-free extracts of the micrococcus provides additional, if less conclusive, support for the conclusion that some organisms produce a single esterase of general specificity rather than several esterases with different specificities. Similar views about other bacterial esterases have been put forward by Hugo \& Beveridge (1962) and Rottem \& Razin (1964).

Augustinsson (196I) proposed that the active centre of all esterases has a characteristic amino-acid sequence but that the rest of the molecule may vary. The latter might have little effect upon enzyme + substrate complex formation, which would account for the high degree of overlapping in hydrolysis of substrates by different esterases. Variations in physico-chemical properties of both the enzyme and the substrate molecules might explain, however, the differences in degree of specificity found with microbial esterases from different sources. Thus the micrococcal lipase preparation was about 50 times more active against tributyrin, 25 times against tridecanoin but only 6 times more active against butterfat than was the lipase from the pseudomonad. This greater specificity of the micrococcal lipase towards esters containing short chain fatty acids was particularly pronounced in the case of the soluble aromatic esters against which the pseudomonad lipase showed almost no activity.

The inhibition of the micrococcal lipase by organophosphorus compounds, by 2,4-dinitrofluorobenzene in alkaline solution and the annulment of metal-ion inhibition by histidine and the absence of inhibition by $-\mathrm{SH}$ reagents suggest that the active centre may contain both serine and imidazole groups (Barnard \& Stein, 1958). The estimated pK values (between $6 \cdot 2$ and $7 \cdot 2$ ) for the hydrolysis of both $o$-nitrophenylbutyrate and emulsified tributyrin are also consistent with an active imidazole centre 
(Gutfreund, 1965). The $\mathrm{pH} /$ activity curves for the hydrolysis of both o-nitrophenylbutyrate and emulsified tributyrin by the micrococcal lipase reached an optimum at pH 8.5 which did not decline with increasing alkalinity. This may be interpreted as evidence for the involvement of an acidic group in the binding of the substrates (Bergmann, Rimon \& Segal, 1958). The low activity towards soluble esters of the pseudomonad lipase did not allow such clear-cut conclusions to be drawn about its active centre, but the data obtained by using the triglyceride emulsion diffusion assay indicates that a serine-imidazole active centre may also be involved.

Grateful acknowledgement is made to Mr T. Morichi for carrying out the gel electrophoresis studies.

\section{REFERENCES}

Alford, J. A. \& Pierce, D. A. (1963). Production of lipase by Pseudomonas fragi in a synthetic medium. J. Bact. 86, 24.

ANDREws, P. (1965). The gel-filtration behaviour of proteins related to their molecular weights over a wide range. Biochem. $J .96,595$.

Augustinsson, K.-B. (I96I). Multiple forms of esterase in vertebrate blood plasma. Annls. N.Y. Acad. Sci. 94, 844 .

Barnard, E. A. \& SteIn, W. O. (I958). The roles of imidazole in biological systems. Adv. Enzymol. 20, $5 \mathrm{I}$.

Bergmann, F., Segal, R. \& Rimon, S. (1958). Effect of pH on the activity of eel esterase towards different substrates. Biochem. J. 68, 493.

Cohen, S., Kurshnick, J. B. \& Purdy, C. V. (1953). Observations on mycobacterial esterases with a series of synthetic substrates. J. Bact. 66, 266.

Cooper, K. E. (1963). The theory of antibiotic inhibition zones. In Analytical Microbiology, Ed. by F. Kavanagh. Chap. I. London: Academic Press.

DAvies, R. (1963). Microbial extracellular enzymes, their uses and some factors affecting their formation. In Biochemistry of Industrial Micro-organisms, Ed. by C. Rainbow and A. H. Rose. Chap. 4. London: Academic Press.

Dowd, J. E. \& RiggS, D. S. (I965). A comparison of estimates of Michaelis-Menten kinetic constants from various linear transformations. J. biol. Chem. 240, 863.

Downey, W. K. \& ANDrews, P. (1965a). Gel filtration applied to the study of lipases and other esterases. Biochem. J. 94, 642 .

DowneY, W. K. \& ANDREws, P. $(1965 b)$. Esterase activity of the non-enzymic proteins of milk and serum. Biochem. J. 96, 2 I C.

Drummond, M. C. \& TAGer, M. (I959). Enzymatic activity of staphylocoagulase. II. Dissociation of plasma clotting from tributyrinase activity. J. Bact. 78, 413.

Fryer, T. F., Reiter, B. \& Lawrence, R. C. (I967). Lipolytic activity of lactic acid bacteria. $J$. Dairy Sci. 50, 388.

Fryer, T. F., LAWREnCE, R. C. \& ReITER, B. (1967). Methods for the isolation and enumeration of lipolytic organisms. J. Dairy Sci. 5o, 477 .

Gelotte, B. (1964). Separation of pancreatic enzymes by gel filtration. Acta chem. scand. 18, 1283.

Gutfreund, H. (1965). An Introduction to the Study of Enzymes. Oxford: Blackwell Scientific Publications.

Hugo, W. B. \& Beveridge, E. G. (1962). A quantitative and qualitative study of the lipolytic activity of single strains of seven bacterial species. J. appl. Bact. 25, 72.

International Union of Biochemistry (1961). Report of the Commission on Enzymes. Oxford: Pergamon. LAMPEN, J. O. (1965). Secretion of enzymes by micro-organisms. Symp. Soc. gen. Microbiol. I5, I15.

Lawrence, R. C., Fryer, T. F. \& Reiter, B. (1967). A rapid method for the quantitative estimation of microbial lipases. Nature, Lond. 213, 1264.

LAWRENCE, R. C. (1967). Microbial lipases and related esterases. Dairy Sci. Abstr. 29, I.

Lund, B. M. (1965). A comparison by the use of gel electrophoresis of soluble protein components and esterase enzymes of some group D streptococci. J. gen. Microbiol. 40, $4 \mathrm{I} 3$. 
Mencher, J. R., NG, H. \& Alford, J. A. (1965). The extracellular nature of the lipase of Pseudomonas fragi. Biochim. biophys. Acta ro6, 628.

Miles, A. A. \& MisRa, S. S. (1938). The estimation of the bactericidal power of the blood. J. Hyg., Camb. 38, 732.

Mounter, L. A. \& Tuck, K. D. (1956). Dialkylfluorophosphatases of micro-organisms. II. Substrate specificity studies. J. biol. Chem. 221, 537.

Nashif, S. A. \& Nelson, F. E. (1953). The lipases of Pseudomonas fragi. II. Factors affecting lipase production. J. Dairy Sci. 36, 47 I.

Pollock, M. R. (I962). Exoenzymes. In The Bacteria, Ed. by I. C. Gunsalus and R. Y. Stanier. Vol. 4, p. I2I. New York: Academic Press.

RotTem, S. \& RAZIN, S. (1964). Lipase activity of mycoplasma. J. gen. Microbiol. 37, I23.

Sierra, G. (1957). Studies on bacterial esterases. Part I. Differentiation of a lipase and two aliesterases during the growth of Pseudomonas aeruginosa and some observations on growth and esterase inhibition. Antonie van Leeuwenhoek 23, 24I.

Smith, G. N., Worrell, C. S. \& Swanson, A. L. (1949). Inhibition of bacterial esterases by chloramphenicol (chloromycetin). J. Bact. 58,803.

SMITH, J. L. \& Alford, J. A. (I966). Inhibition of microbial lipases by fatty acids. Appl. Microbiol. 14, 699.

VIRTANEN, A. I. (I934). On the enzymes of bacteria and bacterial metabolism. J. Bact. $28,447$. 